\title{
TREE STAND OF THE OLD CEMETERY IN LODZ AND PLACE OF THE OLD CEMETERY AMONGST LODZ'S CEMETERIES ALONG THE LODKA RIVER
}

\begin{abstract}
The article concerns tree stand of the Old Cemetery at Ogrodowa street in Lodz. Circumferences of trees at breast height in the main avenue have been measured. Also circumferences of other old trees in the cemetery and two other cemeteries have been measured. Value of tree stand in the Old Cemetery has been assessed.

Assessment of the area and tree stands of former cemeteries in the Lodka valley has been done. Positon and time of foundation of cemeteries in relation to the Lodka River is presented in the paper. The article covers size and distance of cemeteries from the oldest part of agricultural Lodz.
\end{abstract}

Keywords: tree stand, trunk circumference, BHT, area of a cemetery, foundation date, the Old Cemetery in Lodz, natural value.

\section{Introduction}

Cemeteries are generally considered verdant, defined not only by tombs, chapels, sculptures and avenues but also by trees, bushes, creepers and herbaceous species. Plants of different size and habit set the vibe of a sacred place. Some flowers or trees are considered more appurtenant to mood of pensiveness and reminiscing. These are chrysanths, periwinkles among herbaceous plants, ivies among creepers, yews, platycladuses among trees or bushes and many others. Old cemetery in Lodz is often considered the oldest one in Lodz and thus most verdant. It can be assumed that there were at least two earlier cemeteries. The oldest cemeteries in Poland are to be found in closest vicinity of churches. Most probably the oldest church in Lodz was built in XIV or XV century. More concretely between 1364 and 1382 at the capitol of bishopric in Włocławek sat Zbilut Golanczewski. Archbishop Bogoria Skotnicki ruled in Gniezno until 1371. As the second one erected the parish of Lodz upon newly built church during the term of office of Galanczewski, so it is assumed that the first Lodz church was founded between 1364 and 1371 (Krawczyk 2007). 
$Ł$. Krawczyk described the position of the first church as placed on the western side of Piotrków highroad in the region of nowadays Zgierska and Drewnowska streets (Krawczyk 2007). Accordingly to Głąb the church was founded to the north from square of Lodz. It took place between the end of 80-ties of XIV century and 1414 (Głąb 2007).

It may be concluded that the oldest churchyard was founded around the church, the way it was practised in the middle ages. Inhabitants of the town had to bury their dead and ground surrounding the church seems to be the most probable place for natural formation of the graveyard. The area around contemporary the Assumption of the Blessed Virgin Mary church was the oldest of Lodz's cemeteries (Pawlak 2014).

Nonetheless the first cemetery of Lodz was situated at the backyard of nowadays presbytery of the Assumption of the Blessed Virgin Mary church (Grzegorczyk 2011). Arguably, the two cemeteries - around the church and in the rear of the vicarage could function collaterally, at least at intervals. The more revered inhabitants could be buried in the closest vicinity of the gothic wooden church, ordinary inhabitants behind the parsonage.

\section{Aims, scope and methods of the research on tree stands of chosen cemeteries along the Lodka River}

The purpose of this article is to assess the density of contemporary cemeteries, area of decommissioned cemeteries and to reconstruct features of once existing tree stands. The article focuses on stating the level of burial plots density that prevents development of tree stands of natural value. The aim of this article is to present structure and changes of tree stand of the Old Cemetery with special regards to the main alley. This paper examines position, area and time of foundation of cemeteries in relation to the Lodka River.

For the needs of this paper research on stand of the Old Cemetery has been done. Some research, at more limited scope has been done at Mania Cemetery and Doły Cemetery.

At the Old Cemetery circumferences at the breast height (TC) of 102 trees were measured. For needs of the article, not all of the data has been used. For some trees breast height parameter (DBH) was calculated. At Mania and Doły (Catholic part) Graveyards TC of 4 trees were measured, respectively. The measures were carried out with a tape measure. Trees for measurement were chosen on the basis of subjective assessment of their size. The biggest trees were chosen. It doesn't apply to the main avenue in the Old Cemetery. In this case all the trees up to the distance of 5 meters from the kerb of the avenue and with BHT above $9.55 \mathrm{~cm}(30 \mathrm{~cm}$ of circumference) were taken into account. For needs of this paper circumference at the breast height has been used, as idea more frequently used in conservation. 
Location of measured trees of the Old Cemetery, Mania Cemetery and Doły Cemetery has been described in the text.

Characteristics of stand structure for the main avenue of the Old Cemetery has been presented using chart of circumference at the breast height for years 2011 and 2017. The charts have regard to species of trees in the main alley.

On the basis of literature diagram of distance from the former centre of Lodz has been created (Fig. 1). Once existing fort on the Lodka River has been chosen as point zero for the $\mathrm{X}$-axis of the chart. The fort was situated in a close vicinity of the place of crossing the Lodka River and Nowomiejska street. The nowadays crossing is the starting point of the chart. The centres of cemeteries have been placed in the chart with respect to their distance both from the Lodka River and the point zero, that is crossing of the river Nowomiejska street.

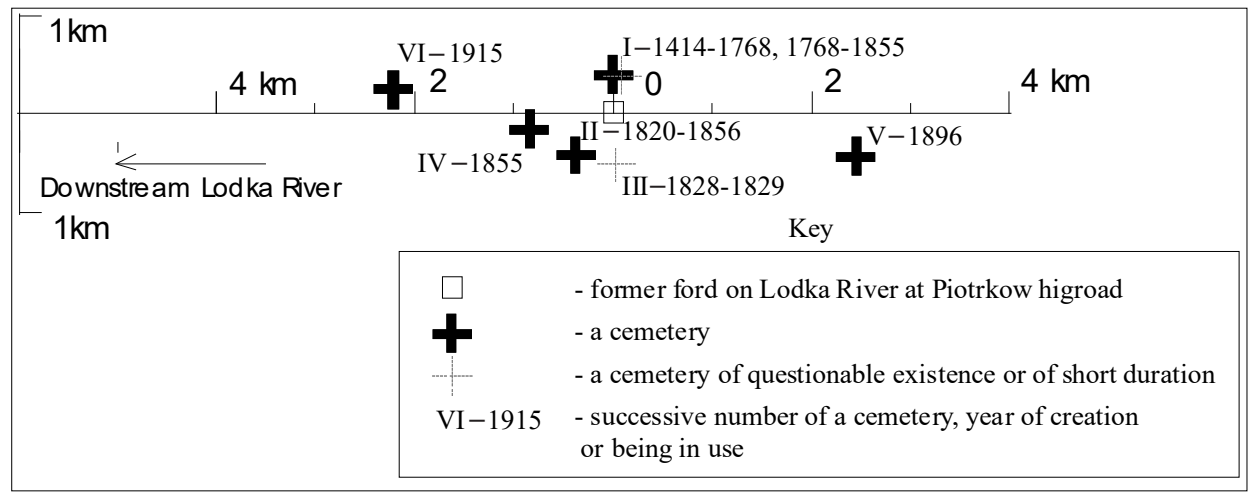

Fig. 1. Position and time of being in use of the cemeteries in relation to the Lodka River Source: own elaboration.

Accordingly to the rule of quantitative generalization (Faliński 1990-1991) chart of the size and distance from the former fort on the Lodka River has been created. Neither the relative position of a cemetery in regard of side of the river nor distance from it were not taken into account for the chart (Fig. 2). The size of non-existing cemeteries at Plac Kościelny has been assessed assuming that density of burying plots was ca. 1715/ha.

Data of density of contemporary 4 Catholic cemeteries and one Evangelical cemetery in the Lodka valley were collected on 2,3 of June, 2020. For collecting the data method of telephone interview with cemetery offices has been used. In cases of Catholic cemeteries particular values of burial plots and areas of cemeteries were obtained. In case of the Evangelical cemetery (part of the Old cemetery) possible data would range in scope of 10 , so an approximation was necessary to make the data more consistent.

Photographic documentation of measured trees has been done. 


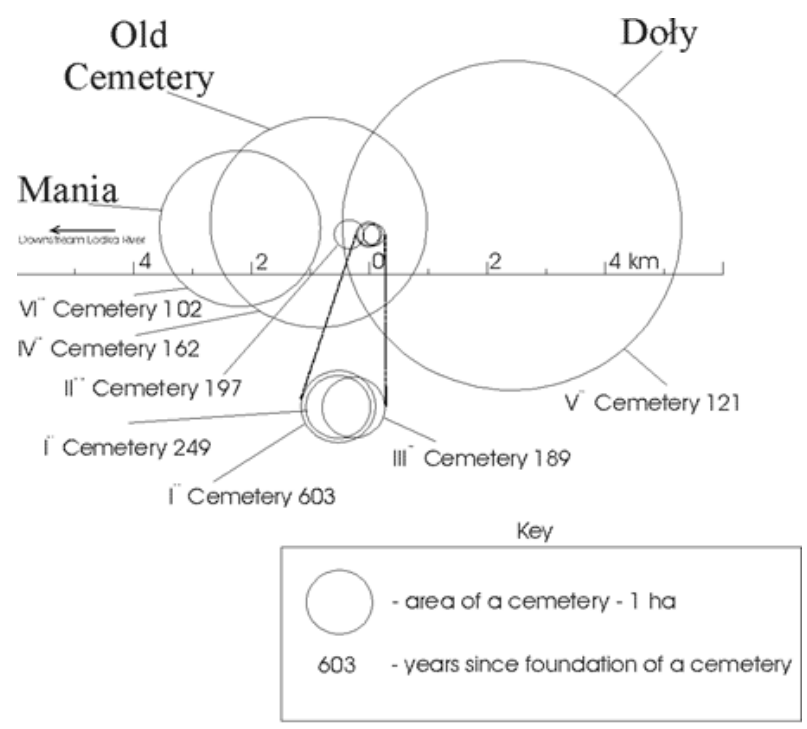

Fig. 2. Areas of cemeteries along the Lodka River

Source: own elaboration.

\section{The size and density of the cemeteries}

Size of cemeteries differs depending on the time of founding a cemetery. As number of inhabitants in a city grew, size of newly founded cemeteries in that city grew as well. The cemeteries in Lodz can be divided, by convention, into two groups. One group consists of old cemeteries, founded before 1820, which is cut-off date of agricultural Lodz's existence. Second group is formed by cemeteries founded after 1820. Old cemeteries include first and second cemetery at Plac Kościelny, cemetery in vicinity of Legionów street. In turn to the second, latter group of cemeteries one can account cemetery at Freedom Square, the Old Cemetery, Doły cemetery and Mania cemetery.

Lodz had around 100 residents at granting city's rights (Grzegorczyk 2011) by Włocławska Chapter in 1414 (Krawczyk 2007). The city had 80 plots at the time (Krawczyk 2007). There is some inconsistence between the data of the two authors as 80 plots given by Krawczyk for times of granting city's rights (Krawczyk 2007) at factor of 5-6 (factor understood as number of family members in an average family of the time, for this paper - factor fm) equals 440 inhabitants of Lodz. The number of families per plot would be higher than one and this would yield even higher number of inhabitants accordingly to number of plots given by Krawczyk (Krawczyk 2007). Referring to the ascertainments of the two authors number of inhabitants was between 100 and 500. Assuming that average number of families 
per plot was definitely higher than one (higher than 1.14) the last number could by far exceed 500 .

A. Zand calculated that in years $1470-1589$ the number of families living in Lodz increased from 44 to 102. At factor fm of 5 to 6 it results in 220-264 to 510-612 people (Grzegorczyk 2011). Relating to inventory of Włocławek domain, Lodz had 80 plots in 1598. Since location of the city the number of plots had been more or less the same. Similar numbers were given by other sources, especially from XVI century (Grzegorczyk 2011).

Noteworthy the name of street - Kościelna was firstly mentioned in 1400 (Krawczyk 2007). This in turn suggests that the area between Old Square and Plac Kościelny was gradually being developed, bespeaking of growing number of inhabitants of Lodz.

Taking into account the above the number of inhabitants of Lodz increased from around 100 to 500 in 1414 to 612 in 1589 . This leads to some estimation on the size of the cemetery. As annually around 1 to $3 \%$ of people may die, the same percentage of burial places gained the cemetery. Taking into account the life expectancy estimated for 30 years in middle ages, not less than $1 \%$ to $3 \%$ of population died annually at times of first church and cemetery existence. In some cases life expectancy for a newborn in central Poland in Middle Ages was even lower than 30 years, only 25,4 years (Budnik, Liczbinska, Gumna 2004). If the burial plots had been in existence for 50 years, the cemetery would have accounted around 50 to 150 burial plots at 100 inhabitants. Therefore very rough estimation leads to conclusion the cemetery ranged from $50-150$ to $250-750$ burial places in 1414 and around 306 to 918 in 1589 . Inhuming the dead at the burial plots of their ancestors would have significantly reduced the above numbers. What is more, as life expectancy was gradually rising, number of burials per given number of inhabitants was falling. Contemporary fatality rate for the whole population of Poland equals 10\%o (Ludność w wieku 60 lat $i$ więcej, 2016). Nowadays average life expectancy has amounted to 73.6 for men, 81.6 for women in 2015 (Trwanie zycia $w 2015,2016$ ). That means even on the premise that fatality rate might rise to more than $10 \%$ for some periods, number of burials in 50 years at 100 newly born inhabitants (for a cemetery) would these days amount to around 20 to 58 only.

Density of burial plots in contemporary Lodz differs. St. Joseph cemetery, which is catholic part of the Old Cemetery, has got ca. 30000 burial plots/10.65 ha, that is 2816 burial plots/ha. Mania cemetery is characterized by very similar value of density, around 30000/10.9 ha, that is 2752 /ha. St. Vincent cemetery (catholic part of Doły cemetery) has got 44111 burial plots/7,63 ha. Thus the density for the cemetery is $5781 /$ ha. Density for a cemetery outside of the Lodka valley, Zarzew cemetery is $4624 /$ ha $(86000 / 18.6 \mathrm{ha})$. Medium value of burial plots density for the four cemeteries equals $3993 / \mathrm{ha}$. 
Density of newly founded burial plots in contemporary Poland is ca. 1715/ha (12000/7 ha) as it is in a newly created part of Łostowicki Cemetery in Gdańsk (Cmentarze-gdanskie 2017). The Evangelical Cemetery founded in 1855 may possibly have similar value of density. Accordingly to data obtained from the cemetery office there are from 500 to 1000 burial plots per cemetery section. There are scarce sections with 100 plots per section. Taking into account there are 50 sections in the cemetery there are from near 25000 to 50000 burial plots. Area of the cemetery is 9.5 ha. Density of burial plots is ranging from ca. 2631/ha to $5263 /$ ha. For some sections it is $526.3 /$ ha. It is clear, that the cemetery is very heterogeneous for this aspect. Some parts of the cemetery have got density close to the highest found within Lodz cemeteries, some have tenfold lower density. According to the site inspection conducted by the author of the paper in 20112020 , the least number of tombs can be found in sections to the south and southwest of The Chapel of Karol Scheibler. This is consistent with distribution of the oldest and biggest trees of the Old Cemetery.

Assuming the density of burial plots at the first Old Lodz's cemetery close to the above mentioned medium value retrieved for the four cemeteries of Lodz $(3993 / \mathrm{ha})$, it is possible to assess its stretch. The area of the first parish cemetery is estimated at around 0.01 ha to 0.19 in 1414 and at about 0.08 ha to 0.23 ha in 1589. The first cemetery in Lodz was situated around or in close vicinity of parish church in Lodz, founded in 1430, at nowadays Plac Kościelny.

The second graveyard was placed also at Plac Kościelny. It was the churchyard of the Assumption of the Blessed Virgin Mary Church, which was built in 17651768. In 1819 the cemetery didn't have fences (Cmentarium.sowa.website 2007). What is more it was in a very poor condition as animals were dragging around corpses of the buried (Cmentarium.sowa.website 2007). Most evidently the cemetery was in very bad shape. Its state was inconceivable as for nowadays standards.

Accordingly to A. Wiercińska (2012) the churchyard was placed at Górka Plebańska (nowadays Plac Kościelny) and in use since XV century till 1855. This means the first cemetery in Lodz and the churchyard of the Assumption of the Blessed Virgin Mary Church were one and the same graveyard. As it didn't have walls exact borders were difficult to define. Its area would be estimated at $0.2 \mathrm{ha}$.

The turning point in development of Lodz's cemeteries was 1820. That year Lodz has been chosen as so called 'factory town'. The decision of Rembielińki's Commission was announced in Kingdom of Poland Vicegerent decree on 18 of September 1820 (Papińska 2001). From then on rising population changed thoroughly the scale of needs for cemeteries and their characteristics. All new reasonable investments had to be in accordance with capitalistic, rapid growth of the city. 
In 1820 a new graveyard was founded at so called Retkińska Road, between contemporary Ogrodowa, Zachodnia and Legionów Street. Its area was 8000 cubits, that is approximately $2600 \mathrm{~m}^{2}(0.26 \mathrm{ha})$. In 1828 the cemetery had to be enlarged by 4380 cubits, that is circa $1402 \mathrm{~m}^{2}$ ( 0.14 ha). Regardless of swampy terrain it had to be enlarged yet many times in years 1838-1855. It took place due to sharp incline in number of Lodz's inhabitants. There were 767 inhabitants of Lodz in 1820, 15500 in 1840 and 40121 in 1865 (Liszewski 1999). This graveyard was closed down in 1856. As it was mentioned, one year earlier the cemetery at Plac Kościelny was officially decommissioned (Cmentarium.sowa.website 2007).

In 1826 the first Evangelical Church of Augsburg Confession parish was founded at Freedom Square in Nowe Miasto. The church was completed in 1829. At the yard the church the first colonists of Protestant religion were buried (Cmentarium.sowa.website 2007). Burials took part there in years 1828-1829 (Wiercińska 2012).

There was a cholera outbreak in Lodz in 1852 . There were 253 victims, including 169 of Catholic confession. This led to overflow of the cemetery at Retkińska road and forced the authorities of Lodz to undertake a decision of creating a new cemetery. In 1854 grounds of the new cemetery were determined by the Lodz magistracy, Custodianship of Catholic Church and Evangelical Church Council. The original area of the graveyard was 8.8 ha. The Evangelical part numbered 3 ha, Catholic 5 ha. The parts were divided by a narrow strip of Orthodox part (0.8 ha) (Pawlak 2014).

The Old Cemetery was founded (on agricultural lands) in 1855 . The consecration of new necropolis took place on $9^{\text {th }}$ of September the same year. The cemetery has been founded on municipal cornfield where three-field system had been practised (Koter 1974).

The magistracy protocol dated 1858 characterized the area of the latter cemetery as rye land of third class and hilly. The magistracy bought the land from 38 owners for 393 roubles. First burials took place at the end of 1854, before the official inauguration of the cemetery (Winnik 2005).

Rapid increase of Lodz population led to overfilling of the graveyard. The number of residents of Lodz grew to 108.45 thousand in 1885 (Liszewski 1999). Rising number of inhabitants of Lodz led to surrounding the cemetery by suburban housing. In 1886 Gubernia authorities forbade further purchases of adjacent grounds. They ordered finding sufficient areas for a cemetery outside of Lodz's borders (Dominikowski 2004).

Lacking in burial plots at the Old Cemetery and risk of necessity of burying the dead at the graveyard's avenues changed the Gubernia authorities' position. The authorities gave consent for joining new areas to the cemetery in 1888 (Wiercińska 2012). The graveyard reached the area of 21 ha. It still wasn't enough for fast growing city. 
Within borders of Lodz there weren't enough burial plots. Population of Lodz reached 168.5 thousand people in 1895 (Janczak 1982). The area of deserted Doły village was chosen for founding a complex of graveyards in 1896 (Wiercińska 2012). Part of the cemetery is placed on the slopes of Lodka River valley. Nowadays the cemetery has got diversified stand, both for its species composition and age structure (Photo 1). Nonetheless the Acer platanoides is prevailing among oldest trees there.

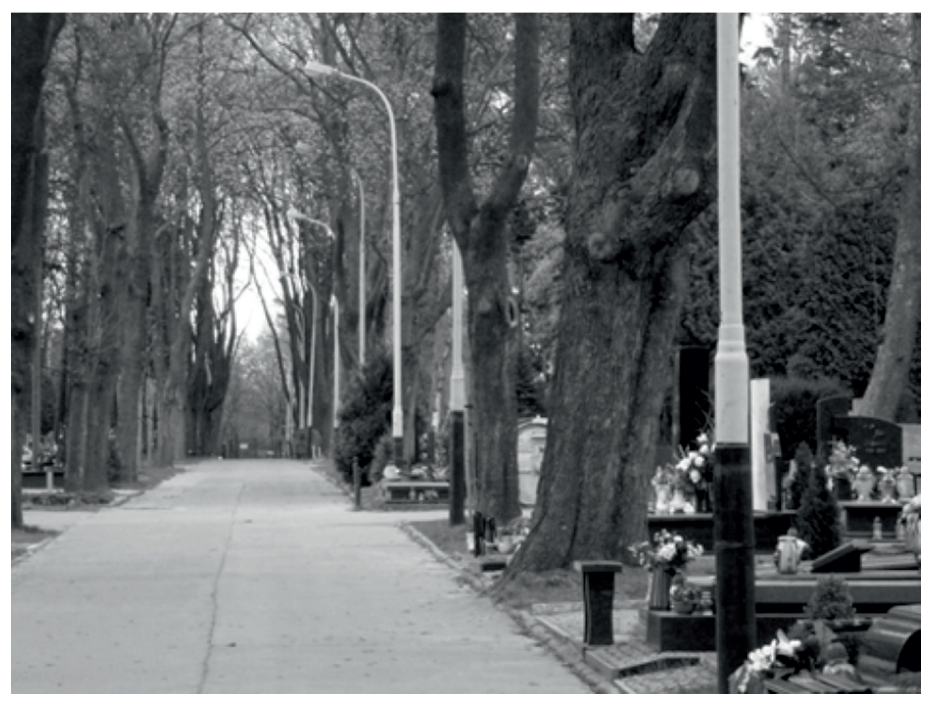

Photo 1. Tree stand at Doły cemetery

Source: photo by T. Otocki.

The subsequent cemeteries were distant from the old center of Lodz and Lodka River. These were Evangelical-Augsburg cemetery at Old Rokicie (1898) and catholic cemetery at Zarzew (1898), nowadays Przybyszewskiego 325 Street. Increase of Jewish society in Lodz led to foundation of Jewish cemetery at Doły village in 1892, nowadays Bracka 40 Street.

$18^{\text {th }}$ of October 1906 territory of Lodz was increased (Wiercińska 2012). The population of Lodz increased to 329 thousand (Janczak 1982).

Lack of cemeteries in western part of Lodz led to foundation of St. Anthony catholic graveyard in Mania quarter, near city forest, todays Solec 11 Street (Wiercińska 2012). It took place in 1915 (Cmentarze-lodz... 2017), a year after Lodz reached 477.9 thousand inhabitants (Liszewski 1999). The area of the cemetery totals $10.9 \mathrm{ha}$. Some old trees on territory of the cemetery are remnants of bygone forest (Cmentarze-lodz... 2017) and may have witnessed of primeval past of the district. The other side of Wieczność Street extends so called Mania forest, retaining many features of natural forest. For example it is characterized by diversity of trees and abundance of undergrowth plants, such as Anemone nemorosa. 
The first cemeteries in Lodz were created generally along Lodka River from east to west successively. Taking into account needs of the western part of the city graveyard in Mania district was the next one in sequence. All of the mentioned above cemeteries except Old Rokicie and Zarzew were built in close vicinity of Lodka River although were set in different distances from local watershed and banks of the river. Jewish cemetery at Bracka 40 is close to Lodka Valley, nonetheless it stretches to vicinity of spring areas of Bałutka (zwik.lodz.rzeki-lodzi 2017) river.

\section{Features of once existing tree stands}

Tree stands of decommissioned cemeteries functioning before the Old Cemetery are difficult to define. It is difficult to assess any features of tree stands of former cemeteries. Contemporary tree stands, are dependent on nowadays land use. Still, the possibility that they refer in a way, for example throughout their species composition, to former land use - cemetery, cannot be profoundly ruled out. Reconstruction of features of once existing tree stands can be based on analysis of iconography and photography.

A figure presenting the Assumption of the Blessed Virgin Mary Church in Lodz, completed 1768, shows trees around the church, probably maples and poplars. In the figure there are 10 trees within a fence around the church, thus on territory of the Assumption of the Blessed Mary Church cemetery (Grzegorczyk 2011). Other source of information may be a photography of Scheibler's chapel in the Old Cemetery. Photographies are accessible at City of Lodz Office page (UMt, Protestantyzm 2020). The photography was taken in 1896 by photographer Bronisław Wilkoszewski. It shows foreground and background of the chapel with some area around it. The photography has been taken towards north-east. Trees are visible in the background, to the right, farther to the east a tree stand is visible, most probably belonging to the main avenue of the Old Cemetery. Assessment of the species of trees doesn't seem to be possible. To the left, behind the chapel there is a tree, probably birch around $10 \mathrm{~m}$ high. There are bushes in the foreground. There is also a photography of newly built Scheibler's chapel, taken probably in the same times. The photography has been take towards south-east. To the right, behind the chapel there are visible leafy trees, several meters high. Taking into account dimensions of the chapel, level from which the picture was taken (roughly $5 \mathrm{~m}$ ) and perspective, one can approximately estimate height of the trees behind the chapel to the east. The height of the chapel is $37 \mathrm{~m}$, it is $25 \mathrm{~m}$ long and $13,5 \mathrm{~m}$ wide. Considering the above the height of the trees, was most probably around $10-15 \mathrm{~m}$ at the end of XIX century. 


\section{Tree stands of cemeteries in vicinity of the Lodka River}

Out of cemeteries in north-eastern, central and western part of Lodz the most valuable as for its natural assets seems to be the Old Cemetery. The graveyard is well known for its old trees and park-like setting. Some trees there are nature monuments (Winnik 2005). Stands at Doły cemetery haven't reached the dimensions of those at Old Cemetery. Nonetheless some areas in Doły cemetery are abundant in trees. Mania cemetery has different character from the Old Cemetery. Trees there are dispersed, growing loosely among tombs; it is possible to see the other end of the graveyard from the vicinity of main entrance. Regardless of their sparsity, the trees of Mania cemetery are supposed to be remainders of anterior forest (Cmentarze-lodz... 2017).

Research on tree stand of the Old Cemetery has been carried out by Winnik (Winnik 2005). The subject of her study has been species diversity of trees and bushes in the Evangelical and Orthodox parts of the Old Cemetery. She also examined the origin of found species. The aim of her study was to present age structure of tree-stands in the cemetery and to carry out inventory of trees and bushes.(Winnik 2005).

A. Winnik started her research on dendroflora of The Old Cemetery on 20.03.2004. She found that dendroflora of the cemetery consists of 98 species. The most frequently verified species were Acer platanoides, Thuja occidentalis, Acer pseudoplatanus, Buxus sempervirens, Rosa sp., Hedera helix, Vinca minor. 11 trees have been taken under species protection, including 9 in evangelical part and 2 in orthodox part (Winnik 2005).

A. Winnik stated that taking into account circumference at $1.3 \mathrm{~m}$ above ground 77 trees could be qualified to be a nature monument (Winnik 2005). Among the trees there are 40 Norway maples (Acer platanoides L.), 13 horse chestnuts (Aesculus hippocastanum L.), 7 black locusts (Robinia pseudoacacia L.), 5 ashes (Fraxinus excelsior L.), 4 sycamores (Acer pseudoplatanus L.), 2 beeches (Fagus sylvatica L.), 2 silver birches (Betula pendula L.), 1 small-leaved lime (Tilia cordata L.), 1 Crimean lime (Tilia x euchlora L.), 1 red horse chestnuts (Aesculus $x$ carnea L.), 1 European white elm (Ulmus laevis L.).

A. Winnik posited considering the maple-beech-hornbeam avenue in eastern part of Evangelical cemetery as a monument of nature (Winnik 2005). She concluded occurrence of 4 tree specimens recognised as monuments of nature within the avenue. What is more she found there 11 tree specimens qualified for protection as nature monuments.

Three species of strict protection were concluded by A. Winnik on the area of the cemetery (Winnik 2005). These were: Hedera helix, Lonicera periclynemum, Vinca minor. There was also one species of partial protection - Taxus baccata. 
Research conducted in years 2016, 2017 confirms the value of stands at the Old Cemetery found by A. Winnik (Winnik 2005). Trunk circumferences at $130 \mathrm{~cm}$ (TCs) of the measured trees in western part of Evangelical graveyard exceed $400 \mathrm{~cm}$. These were one specimen of Quercus robur, trunk circumference at $130 \mathrm{~cm}$ (TC) $481 \mathrm{~cm}$ (Photo 2), two specimens of Acer platanoides, TC $401 \mathrm{~cm}$, $485 \mathrm{~cm}$ (Photo 3).
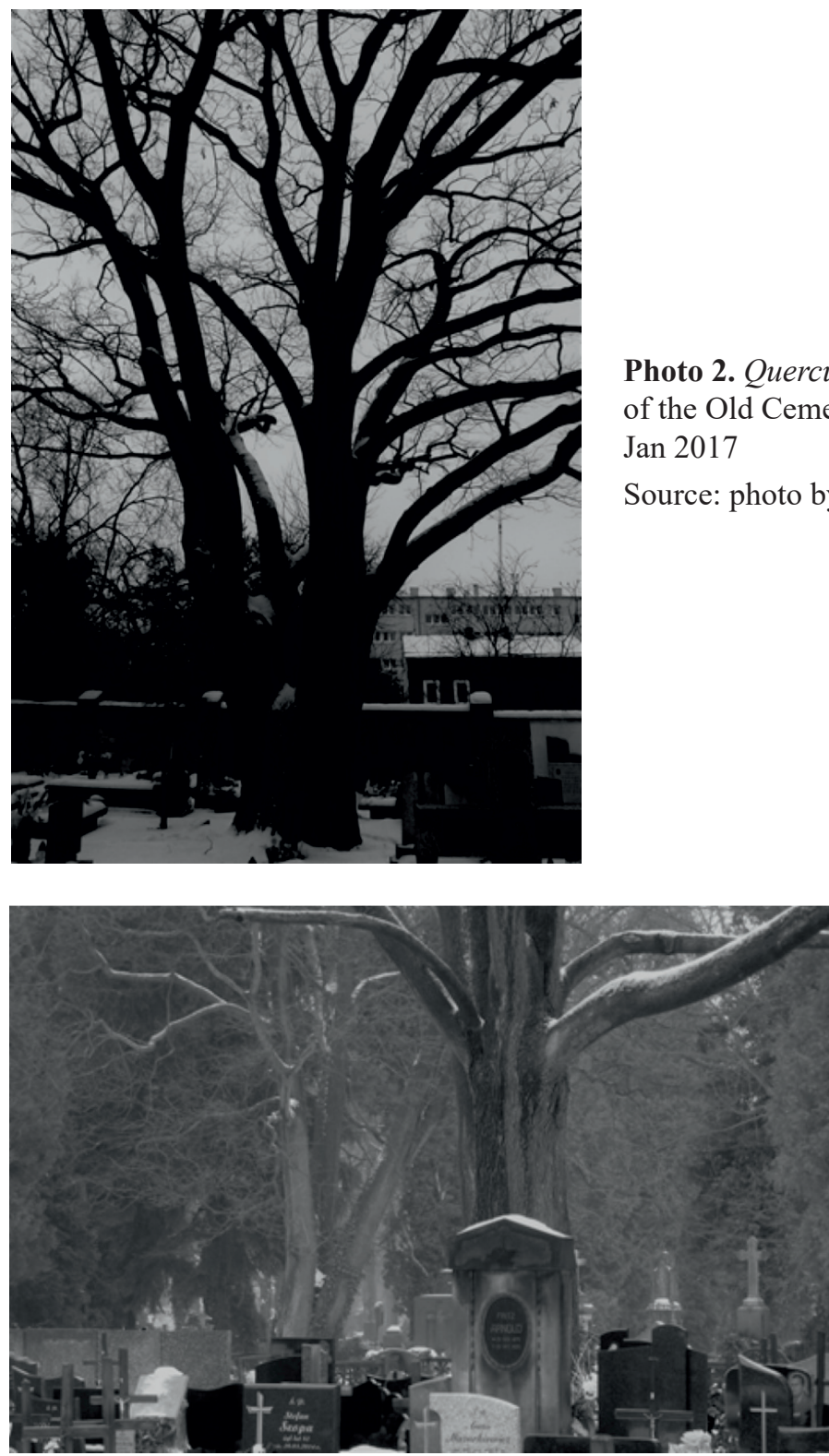

Photo 2. Quercus robur in western part of the Old Cemetery, TC $481 \mathrm{~cm}$, Jan 2017

Source: photo by T. Otocki.
Photo 3. Acer

platanoides in western part of the Old

Cemetery, TC $401 \mathrm{~cm}$ (the foreground), TC $485 \mathrm{~cm}$

(the background), Jan 2017

Source: photo by T. Otocki. 
What is more in south-western part of the cemetery there are other trees distinguishing themselves from other trees by their dimensions. There are two specimens of Acer platanoides, TC $388 \mathrm{~cm}$ and $250 \mathrm{~cm}$ in 2017 . There is also one specimen of Robinia pseudoacacia that reached TC of $340 \mathrm{~cm}$ the same year (Photo 4).

The dimensions of these trees can be closely related to history of the area. If the territory of nowadays cemetery was formed by fields belonging to 38 owners it is possible that there were 37 to 39 balks. The oldest trees could grow there before the inauguration of the cemetery. Circumferences of some tress in central and south-western part of Evangelical cemetery suggest that these trees could be over 170 years old. Taking into account table of trees sizes by L. Majdecki (Tabela wiekowa drzew, 1980), the biggest oak in the western part of the Evangelical Cemetery is about 333 years old.

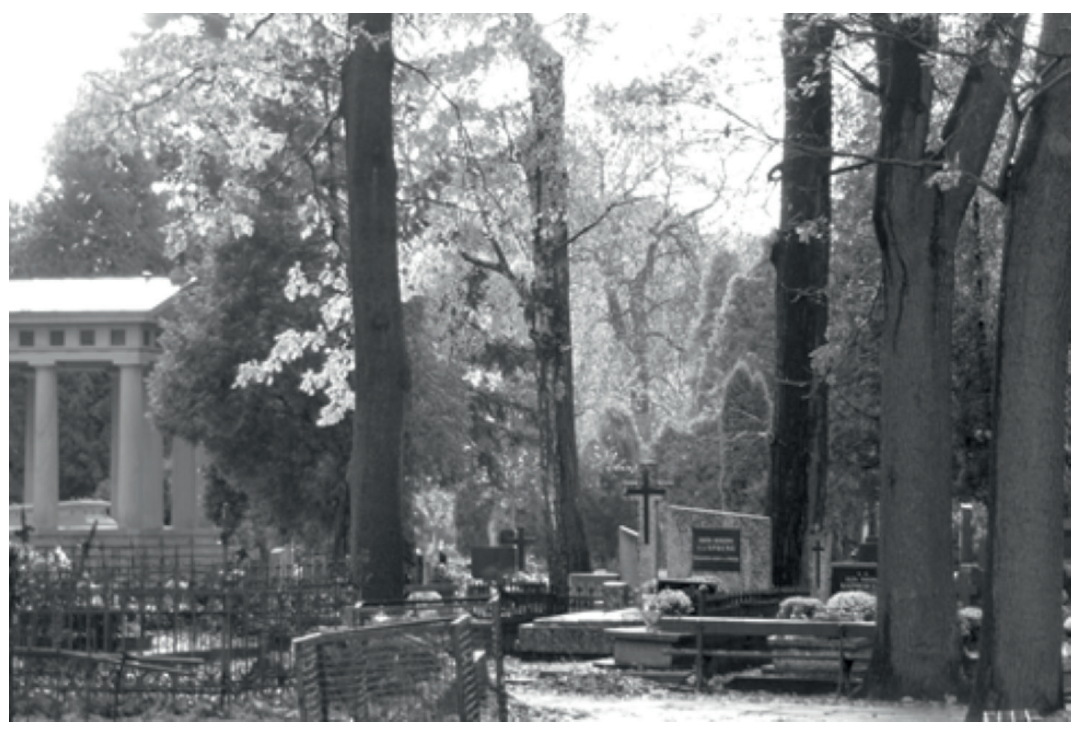

Photo 4. Tree stand in central part of the Old Cemetery, autumn, $2^{\text {nd }}$ of Nov 2016 Source: photo by T. Otocki.

Dimensions of trees in the maple-beech-hornbeam avenue in Eastern part of Evangelical cemetery, described by A. Winnik are diversified (Winnik 2005). Research conducted by author of this paper in 2011 and 2017 shows some aspects of this diversification (Table 1, Table 2, Fig. 3). 
Table 1. Trunk circumferences of trees in the main alley in the Old Cemetery in 2011*

\begin{tabular}{|c|c|c|c|c|c|c|c|c|c|}
\hline $\begin{array}{l}\text { Oak } \\
\text { (Qr) }\end{array}$ & $\begin{array}{l}\text { Horse } \\
\text { chest- } \\
\text { nut } \\
\text { (Ah) }\end{array}$ & $\begin{array}{l}\text { Silver } \\
\text { birch } \\
\text { (Bv) }\end{array}$ & $\begin{array}{l}\text { Com- } \\
\text { mon } \\
\text { horn- } \\
\text { beam } \\
(\mathrm{Cb})\end{array}$ & $\begin{array}{l}\text { Syca- } \\
\text { more } \\
\text { (Aps) }\end{array}$ & $\begin{array}{l}\text { Com- } \\
\text { mon ash } \\
(\mathrm{Fe})\end{array}$ & $\begin{array}{c}\text { Com- } \\
\text { mon } \\
\text { Aspen } \\
(\mathrm{Pt})\end{array}$ & $\begin{array}{l}\text { White } \\
\text { cedar } \\
\text { (Toc) }\end{array}$ & $\begin{array}{c}\text { Com- } \\
\text { mon } \\
\text { beech } \\
(\mathrm{Fs})\end{array}$ & $\begin{array}{c}\text { Norway } \\
\text { maple } \\
\text { (Ap) }\end{array}$ \\
\hline \multirow[t]{16}{*}{287} & 177 & 201 & 133 & 140 & 100 & 157 & 41 & 269 & 67 \\
\hline & & & 189 & 181 & 141 & 162 & & 335 & 159 \\
\hline & & & & 203 & & & & 366 & 164 \\
\hline & & & & & & & & 377 & 182 \\
\hline & & & & & & & & & 184 \\
\hline & & & & & & & & & 185 \\
\hline & & & & & & & & & 212 \\
\hline & & & & & & & & & 256 \\
\hline & & & & & & & & & 264 \\
\hline & & & & & & & & & 269 \\
\hline & & & & & & & & & 276 \\
\hline & & & & & & & & & 278 \\
\hline & & & & & & & & & 291 \\
\hline & & & & & & & & & 293 \\
\hline & & & & & & & & & 308 \\
\hline & & & & & & & & & 339 \\
\hline
\end{tabular}

*Abbreviations for names of the species are the same for Table 1 and Fig. 3. Figures in $\mathrm{cm}$.

Table.2. Trunk circumferences of trees in the main alley in the Old Cemetery in 2017*

\begin{tabular}{cccccccccc}
\hline Oak & $\begin{array}{c}\text { Horse } \\
\text { chest- } \\
\text { nut } \\
(\mathrm{Ah})\end{array}$ & $\begin{array}{c}\text { Silver } \\
\text { birch } \\
(\mathrm{Bv})\end{array}$ & $\begin{array}{c}\text { Com- } \\
\text { mon } \\
\text { horn- } \\
\text { beam } \\
(\mathrm{Cb})\end{array}$ & $\begin{array}{c}\text { Syca- } \\
\text { more } \\
(\mathrm{Aps})\end{array}$ & $\begin{array}{c}\text { Com- } \\
\text { mon ash } \\
(\mathrm{Fe})\end{array}$ & $\begin{array}{c}\text { Com- } \\
\text { mon } \\
(\mathrm{Pt})\end{array}$ & $\begin{array}{c}\text { White } \\
\text { cedar } \\
(\mathrm{Toc})\end{array}$ & $\begin{array}{c}\text { Com- } \\
\text { mon } \\
\text { beech } \\
(\mathrm{Fs})\end{array}$ & $\begin{array}{c}\text { Norway } \\
\text { maple } \\
(\mathrm{Ap})\end{array}$ \\
\hline 292 & 178 & 204 & 136 & 170 & 103 & 170 & 41 & 270 & 82 \\
\hline & & 195 & 187 & 144 & 177 & & 335 & 174 \\
\hline & & & 203 & & & & - & 177 \\
\hline
\end{tabular}


Table 2. continued

\begin{tabular}{|c|c|c|c|c|c|c|c|c|c|}
\hline $\begin{array}{l}\text { Oak } \\
\text { (Qr) }\end{array}$ & $\begin{array}{l}\text { Horse } \\
\text { chest- } \\
\text { nut } \\
\text { (Ah) }\end{array}$ & $\begin{array}{l}\text { Silver } \\
\text { birch } \\
(\mathrm{Bv})\end{array}$ & $\begin{array}{l}\text { Com- } \\
\text { mon } \\
\text { horn- } \\
\text { beam } \\
(\mathrm{Cb})\end{array}$ & $\begin{array}{l}\text { Syca- } \\
\text { more } \\
\text { (Aps) }\end{array}$ & $\begin{array}{l}\text { Com- } \\
\text { mon ash } \\
(\mathrm{Fe})\end{array}$ & $\begin{array}{l}\text { Com- } \\
\text { mon } \\
\text { Aspen } \\
(\mathrm{Pt})\end{array}$ & $\begin{array}{l}\text { White } \\
\text { cedar } \\
\text { (Toc) }\end{array}$ & $\begin{array}{l}\text { Com- } \\
\text { mon } \\
\text { beech } \\
\text { (Fs) }\end{array}$ & $\begin{array}{c}\text { Norway } \\
\text { maple } \\
\text { (Ap) }\end{array}$ \\
\hline & & & & & & & & & 190 \\
\hline & & & & & & & & & 213 \\
\hline & & & & & & & & & 246 \\
\hline & & & & & & & & & 256 \\
\hline & & & & & & & & & 266 \\
\hline & & & & & & & & & 268 \\
\hline & & & & & & & & & 268 \\
\hline & & & & & & & & & 285 \\
\hline & & & & & & & & & 299 \\
\hline & & & & & & & & & 316 \\
\hline & & & & & & & & & 317 \\
\hline & & & & & & & & & 348 \\
\hline
\end{tabular}

*Abbreviations for names of the species are the same for Table 2 and Fig. 3. Figures in $\mathrm{cm}$.

A

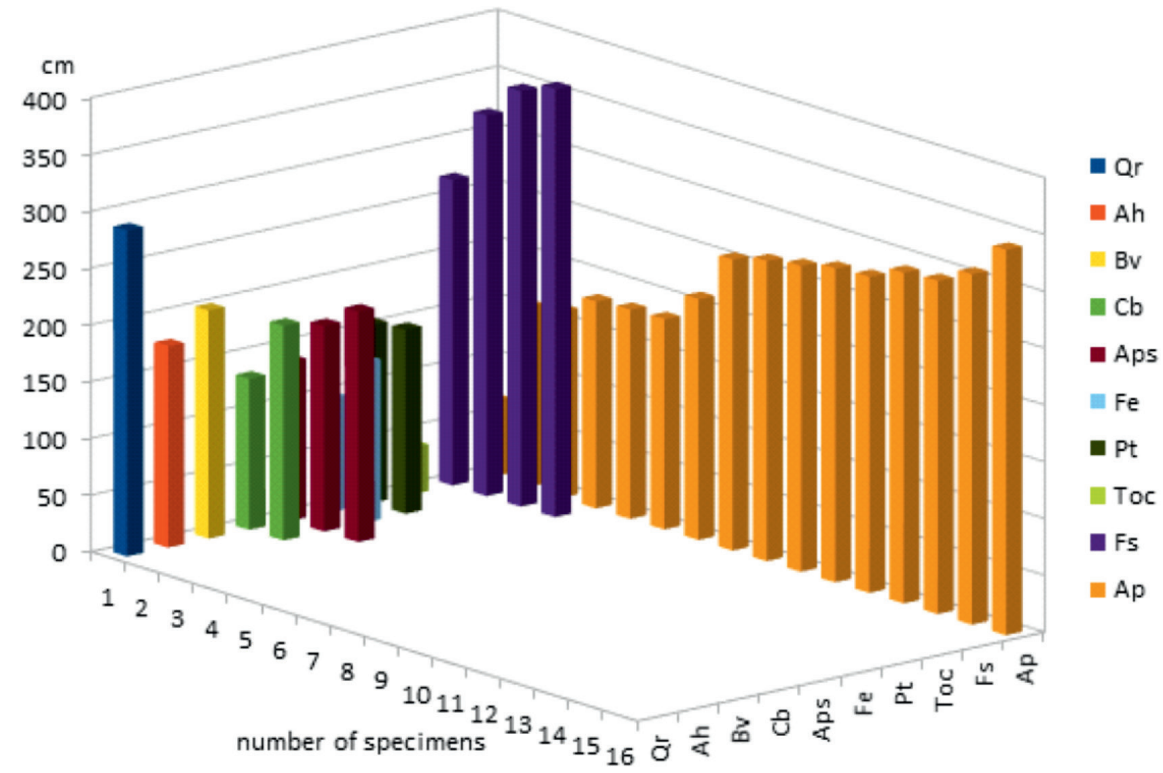




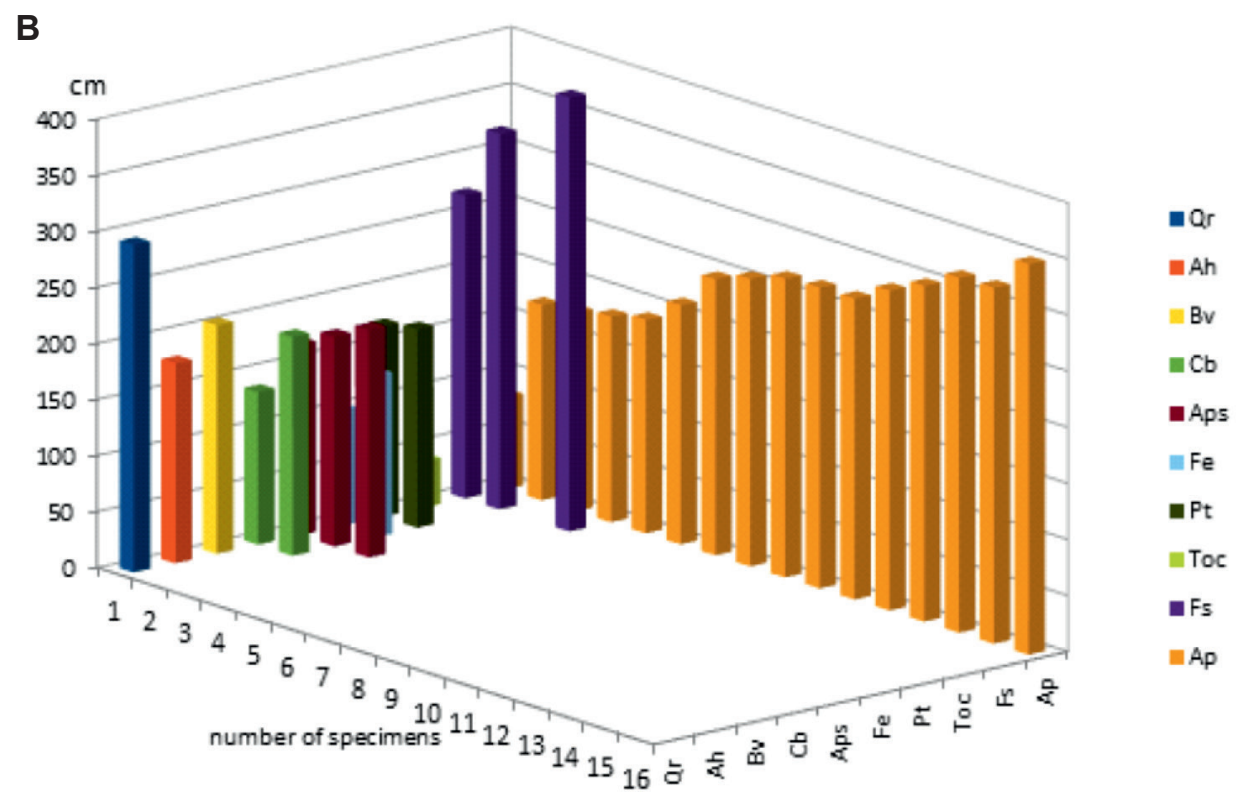

Key

Qr-Quercus sp.

Ah - Aesculus hippocastanum

$\mathrm{Bv}$ - Betula verrucosa

$\mathrm{Cb}-$ Carpinus betulus

Aps - Acer pseudoplatanus

$\mathrm{Fe}-$ Fraxinus excelsior

$\mathrm{Pt}-$ Populus tremula

Toc - Thuja occidentalis

Fs - Fagus sylvatica

Ap - Acer platanoides

Fig. 3. Comparison of circuits of trees in the main alley in Evangelical part of the Old Cemetery in Lodz in 2011 (A) and 2017 (B)

Source: own elaboration.

There are 9 specimens of Acer platanoides with TC above $250 \mathrm{~cm}$, including 2 specimens with TC above $300 \mathrm{~cm}$ in 2011 and 3 in 2017. There are 2 specimens of Fagus sylvatica, characterized by TC above $330 \mathrm{~cm}$. One beech tree of the diameters, present in 2011 was missing in 2016. Different pace of growth for individual specimens of Acer platanoides is well indicated in Fig. 3B, compared with Fig. 3A. There is one specimen that has TC close to $350 \mathrm{~cm}$ (TC $348 \mathrm{~cm})$. There is one Betula verrucosa with TC exceeding $200 \mathrm{~cm}$. Quercus sp. specimen is partly covered in remnants of cut off Hedera helix sprigs that influence its circumference measurement, somewhat inflating it. Because of the dimensions of the trees, the alley can be considered the main in the cemetery (Photo 5, 6). 


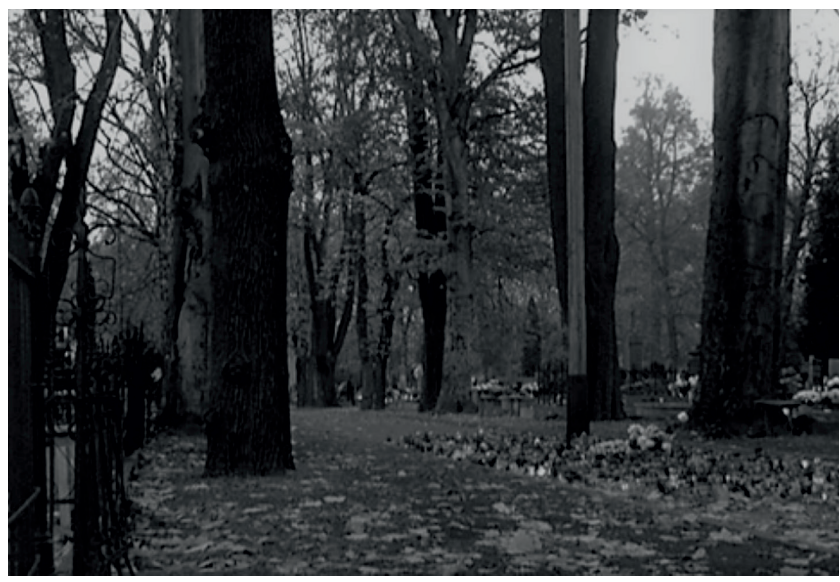

Photo 5. The main avenue in the Old Cemetery,

Nov 2011

Source: photo by T. Otocki.

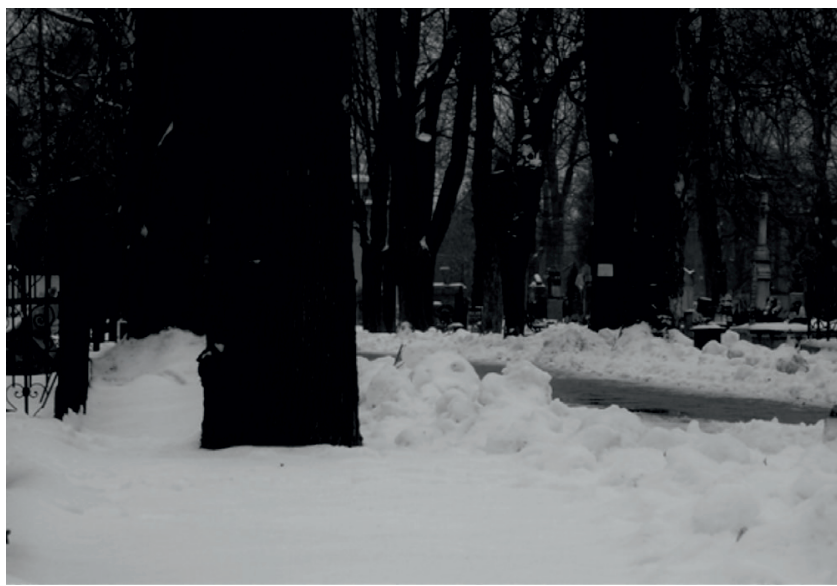

Photo 6. The main avenue in the Old Cemetery, Jan 2017

Source: photo by T. Otocki.

There is a parallel avenue at the cemetery, consisting of oaks (Quercus robur or Quercus sessilis) (Photo 7). It is situated about $20 \mathrm{~m}$ to the west from the maple-beech-hornbeam avenue. The value of TC for one of the trees in the oak avenue was $226 \mathrm{~cm}$. That was one of biggest trees in the alley. There are obvious differences between the two avenues. There are at least 10 species in the main alley and 2 in the oak alley. Trees grow in irregular distances from each other and from the axis of the alley in case of the maple-beach-hornbeam alley and in relatively regular distances in the oak alley. Two lines of trees are placed closer to each other in case of the oak avenue. The trees are characterised by similar dimensions, that suggests they were planted at the same time.

The biggest measured trees at Doły cemetery were 3 specimens of Acer platanoides with following TCs: $274 \mathrm{~cm}, 258 \mathrm{~cm}, 251 \mathrm{~cm}$. Specimen of TC 258 was partly covered by Hedera helix, what might slightly increase its TC. One measured Tilia platyphyllos had TC totalling $245 \mathrm{~cm}$. All of the trees were measured in southern part of the cemetery, close to Telefoniczna street, along the main avenue. 
Trees measured at Mania cemetery belonged to more species, and had lower TCs. Specimen of Quercus robur had TC amounting to $261 \mathrm{~cm}$. Specimen of Quercus rubra had TC totalling $247 \mathrm{~cm}$. Tilia cordata was characterised by TC of $188 \mathrm{~cm}$ and Picea abies by TC of $174 \mathrm{~cm}$ (Photo 8).
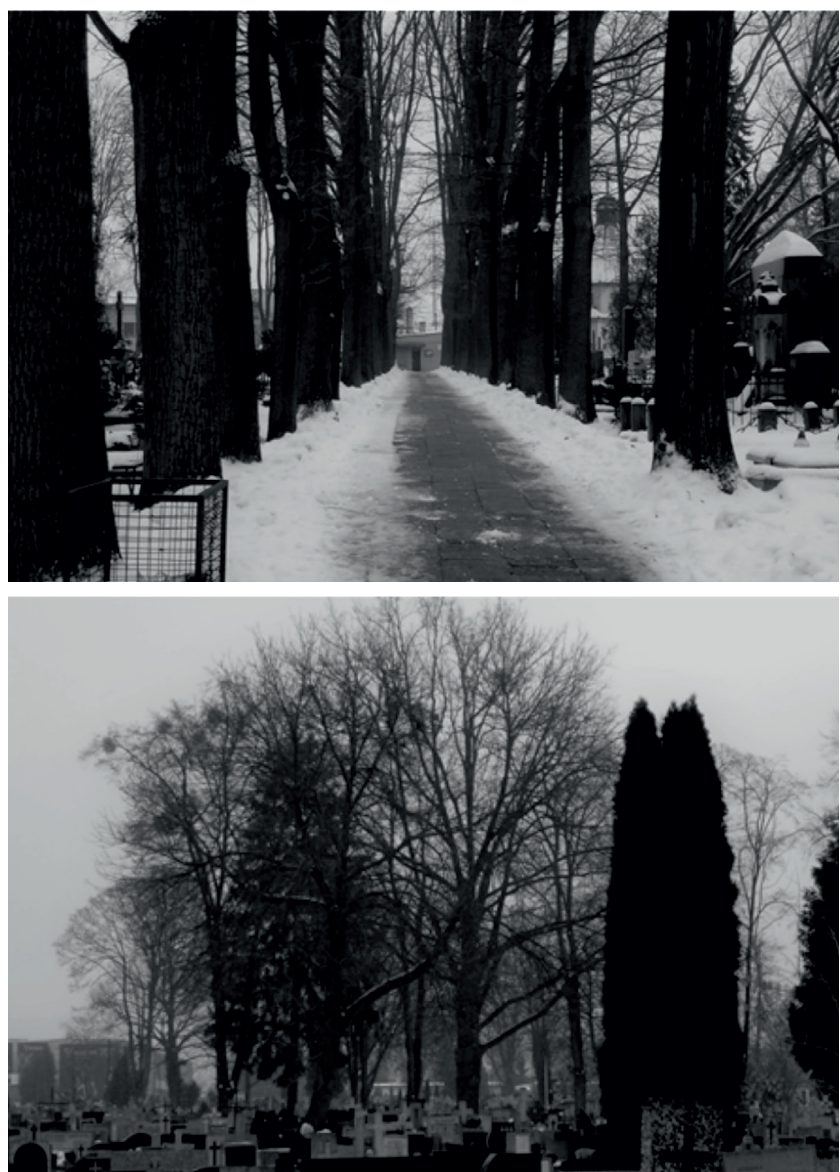

Photo 7. The oak avenue in the Old Cemetery, Jan 2017

Source: photo by T. Otocki.
Photo 8. Trees stands are sparse at Mania cemetery, Jan 2017

Source: photo by T. Otocki.

\section{Discussion}

The Old Cemetery is one of 3 cemeteries situated in the vicinity of Lodka River. It is possible to present its placement, size and time of establishment in relation to other cemeteries and the Lodka River (Fig. 1, 2).

It is very distinctive, that cemeteries established before 1821 were small. In 1808 Lodz had 434 residents. The fraction of Jewish in Lodz was rising (around 60 people after 1808), they were numerous enough to found their own cemetery between Rybna, Bazarowa, Limanowskiego and Zachodnia street in 1811 (Wiercińska 2012). At the time there was a small tributary of the Lodzka river, nowa- 
days dried out. Shape of its valley is visible nowadays in grassy area between Limanowskiego and Drewnowska street, to the north of Karskiego street. As it was mentioned above Lodz in 1820 had 767 inhabitants. Two cemeteries weren't sufficient for burying the dead. In 1820 a new cemetery was founded, enlarged in 1828 , totalling then to 0,4 ha, probably 2 times bigger then the cemetery at Plac Kościelny. Regardless of latter enlarging, the cemetery at Legionów street couldn't have been vast. The first Evangelical cemetery, functioning only 2 years doesn't change the overall picture. All the mentioned cemeteries were placed no farther to north or south of Lodka River that $500 \mathrm{~m}$ and no farther than $500 \mathrm{~m}$ to the west. The subsequent 3 cemeteries were placed not farther to the west or east from the fort on the Lodka River than $2.5 \mathrm{~km}$. As for the distance to south or north of the river, the cemeteries are characterised by the same value (Fig. 1). Regardless of manifold increase of cemeteries area they follow the same pattern of distance from the Lodka River (Fig. 1,2). The growth of distances to the west or east after 1820 is derived from the growth of Lodz. It is possible to talk about a group of cemeteries along the Lodka River probably because slopes of the river were in agricultural use. Meridianal development of Lodz after 1820 might left the Lodka valley undeveloped, making it a good area for foundation of consecutive cemeteries.

The size of the cemeteries grew accordingly to number of residents of Lodz. The first cemeteries along the Łódka river were decommissioned as too small, also due to sanitary reasons. Area of the first cemeteries could range from 0.01 ha or 0.04 ha at the beginning of XV century to 0.23 ha or 0.54 ha at the end of XVI century, depending on burial plots density. Assuming that possible cemetery at Górka Plebańska (Grzegorczyk 2011) would be treated as one with the cemetery around the Assumption of the Blessed Virgin Mary church, the latter values are more probable.

The Old Cemetery is characterised by rich tree stands. There are many old trees, parts of the Evangelical cemetery are covered by canopy. Trees are twined with ivy, what combined with dimensions of trees makes the cemetery exceptional. The two other cemeteries - Doły cemetery and Mania cemetery aren't that valuable as for their stands. Trees there are smaller and there is fever of them. Value of stands seems to depend more on age and history of the area of cemetery than on its size (Fig. 1, 2).

Doły cemetery is actually a conglomerate of 7 cemeteries. The municipal cemetery seems to be the most valuable as for its stands. The oldest trees are placed at the maple avenues stretching across the cemetery (Photo 9).

Trees between tombs are smaller thus younger, although there are some old trees among them.

Cumulative value of TCs for 3 biggest measured trees at the 3 cemeteries seems to attest, that the older cemetery, the bigger trees. The cumulative value 
for the Old Cemetery (Evangelical part) is $1367 \mathrm{~cm}$, for Doły (municipal part) cemetery it is 783 , for Mania cemetery it is 696 . Years from foundation of the cemeteries total respectively: 165,124 and 105 . To put it other way this is in relative values 1.96:1.13:1 respectively for TCs and 1.57:1.18:1 respectively for ages of cemeteries. This also confirms the value of stands of the Old Cemetery.

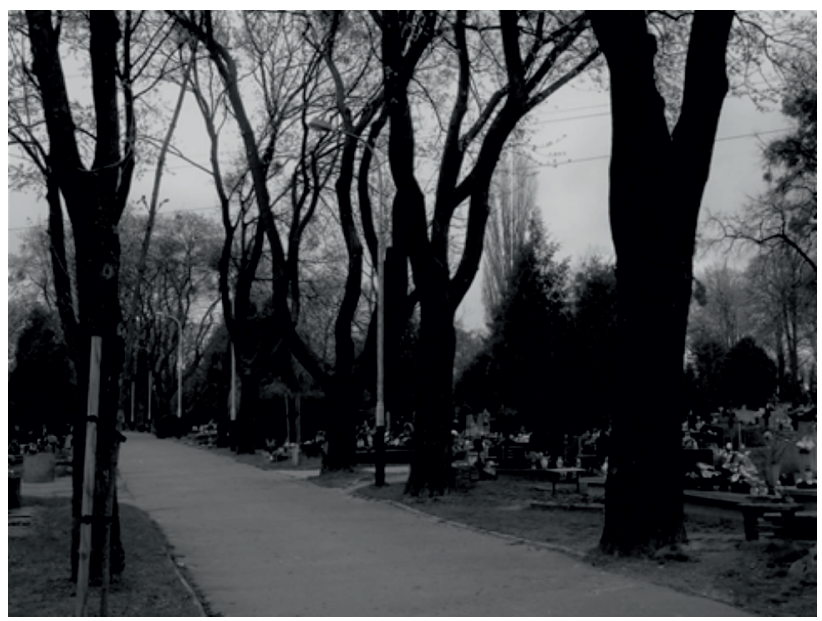

Photo 9. Main maple avenue at Doły municipal cemetery, April 2017 Source: photo by T. Otocki.

Accordingly to (Geoserwis, 2020) there are 5 trees that are monuments of nature in the Evangelical Cemetery. One of them is most unusual dimensions is the oak in western part of the cemetery. Accordingly to documentation (Dziennik Urzędowy Województwa Łódzkiego, 1990) not later than in 1990 the biggest oak in western part of the necropolis reached TC $375 \mathrm{~cm}$. TC of the tree measured in 2011 was $465 \mathrm{~cm}$, in $2016482 \mathrm{~cm}$. That would mean an increase of BHT from $148 \mathrm{~cm}$ to $153 \mathrm{~cm}$, that is by $5 \mathrm{~cm}$ in 5 years (2011-2016). Natural value of the tree can be better depicted by comparison. The biggest tree enlisted by City of Lodz Office is an oak in Źródliska Park. It's TC in 1996 was 475 cm, so it's BHT was then $151 \mathrm{~cm}$.

There were at least 3 cemeteries preceding the Old Cemetery in Lodz. It is difficult to determine whether if there were any stands and assess their value. This is due to the fact the 3 cemeteries are decommissioned. An attempt of determination the size of the cemeteries was undertaken with overall approach, that the bigger cemetery, the higher probability of existence of tree stand within a cemetery. Due to some inconsistencies in data, possible size of cemeteries ranged significantly. Nevertheless the cemeteries had to be relatively small (around 0,25 ha or less), mainly due to small number of inhabitants of pre-industrial Lodz. Thus probability of existence of tree stands on them is low. Trees were probably treated as a source of firewood and it was only sacred character of a cemetery that would reduce felling. 
Both iconographical and photographical sources are valuable as for information about former tree stands of cemeteries. They allow to gain knowledge on presence of tree stand in a cemetery. This concerns both existing and decommissioned cemeteries. Depending on trustworthiness of iconography and quality of photography it is possible to assess height, placement and species composition of tree stands.

There is also question of relation of density of burial plots to abundance of trees in a particular cemetery. An idea that the lower density of burial places means higher chance of developing tree stand seems to be obvious. The question to be answered is, what is the level of density at which chances for development of tree stands of natural value get higher? This can be done with respect to collection of data concerning the most valuable trees of particular cemeteries.

The density of burial plots in the Old Cemetery (Evangelical part) is variable for its different parts, let arbitrary choose the middle of retrieved data for density which is 2631 /ha. For Doły (Catholic part) cemetery it is $5781 /$ ha, for Mania cemetery it is 2752 ha. The above data presented in relative values is respectively $0.95: 2.1: 1$. Overall density of burial plots seems to correspond with the value of tree stands, taking into account that tree stand at the municipal part of Doły cemetery are older and more numerous and more valuable to those at the catholic part of the cemetery. Nonetheless the Evangelical Part of the Old cemetery characterised by valuable trees has got the lowest density of burial plots. Taking into account the quarters with the lowest density within the cemetery, placed to south and south-west and east of Scheibler's chapel the relative values are $0.19: 2.1: 1$. This shows that loosely growing between tombs, valuable tree stands may develop when density of burial places is 5 times lower than typical for Lodz's cemeteries. If the underlying data is average density for investigated Lodz cemeteries (3993/ha), the outcome will be more significant. Let average density $3993 /$ ha $=1$. Then relative values for the quarters, the two cemeteries and the average are: $0.13: 1,45: 0,68: 1$. This means development of loose group of old, valuable trees would be possible if density of burial places is close to 8 times lower than the average. The above calculations depend on reliability of data obtained from cemetery offices. Discrepancies of data may depend on different ways of collecting data. Also former ways of demarcating the plots may influence the number of tombs on particular area. As conducted interview show practices of joining adjacent tombs belonging to one family, lower size of burial places for children, reduction of spacing between the tombs, presence of mass graves can lead to difficulties with quoting fully reliable data on number of burial places in a cemetery. Catholic cemeteries in Lodz has got highest burial places densities and lowest qualities of tree stands, as most of funerals of inhabitants takes place there. Relation between burial places density and value of tree stands would require further investigation. 
The comparison of the outcome of TCs measured at the Old Cemetery in 2011 and 2017 presents pace of growth of the trees. The increase of TCs is different for each tree, in some cases it wasn't measured. A tree may not grow because of its health status. The same TC after 6 years may be also a as measurement error as it can reach about $3 \mathrm{~cm}$ in case of old trees. The growth of trees in the main avenue of the Old Cemetery ranges from 0 to 34.2 negative growth of Acer platanoides are most probably TC reading error. Still it might happen that bark of the tree has been reduced. Trees may be used for tacking notices on them. Medium value of TC growth is $9.3 \mathrm{~cm}$ for all the trees of the main avenue and $12,4 \mathrm{~cm}$ for Acer platanoides specimens in that alley. The ongoing growth of the trees underlines their value. They have reached impressive trunk circumferences and they are gradually reaching primeval dimensions.

On-site verification shows that contemporary relation of some individuals to natural values of the cemeteries is far from being appropriate. Shoots and trunks of old ivies are being cut down, especially in the central part of the Evangelical cemetery. The biggest flowering ivy specimens should be protected as nature monuments.

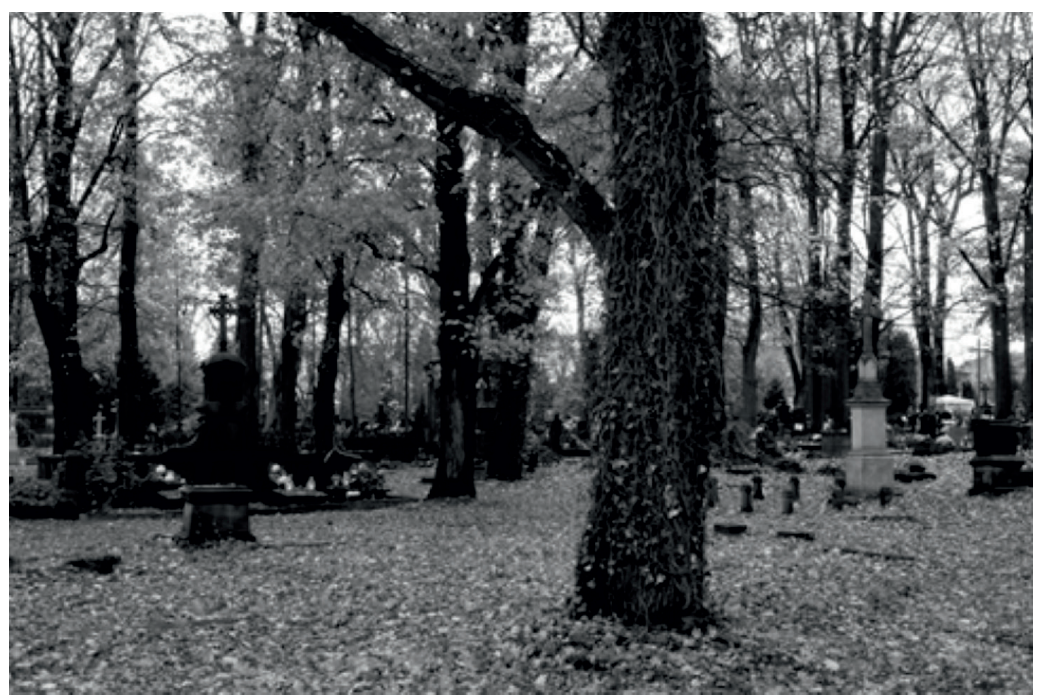

Photo 10. Cut down trunks and shoots of ivy on a trunk of tree in central part of the Old Cemetery

Source: photo by T. Otocki.

Extensive crown lifting of many trees takes place, especially at Catholic part of the cemetery. This is highly reprehensible, as this activity harms the trees, especially because of leaving big wounds and reducing foliage area. Besides 
it rises centre of gravity of a given tree. Functions of avenues, such as wind protection and shading are reduced by high pruning. Avenue trees irremediably lost their habits.

\section{Conclusion}

The density of burial plots in contemporary cemeteries taken into account differ. The quotient of the highest to lowest density equals $2.1(5781 / \mathrm{ha} / 2752 / \mathrm{ha})$.

The cemeteries existing before 1821 were relatively small and are now decommissioned. The cemeteries created after 1820 along Lodka River were about 100 times bigger as for their area and trees there were treated as integral part of the cemetery.

Determination of old cemeteries tree stands demand further research. Nonetheless presence and species composition for one case have been stated on basis of iconographic source. Analysis of the source leads to conclusion, that tree stand was to underline separateness of a graveyard. The presence of trees placed around the Assumption of the Blessed Virgin Mary Church in Lodz in 1768 accented also individuality of sacred character of the church compound. Analysis of photographic sources depicting the Old Cemetery in 1896 show presence of tree stand of the main alley and height of tree stand exceeding $10 \mathrm{~m}$.

Probability of valuable tree stands development depends on density of burial plots. The density that is 5 to 8 times lower than average allows formation of valuable tree stands. At higher densities tree stands can be present in form of avenues.

The most valuable tree stand is present at the Old Cemetery. The biggest maple Acer platanoides reached there TC totalling $485 \mathrm{~cm}$ and the biggest oak Quercus robur had TC of $481 \mathrm{~cm}$. There are two valuable avenues at the cemetery. The eastern the maple-beech- hornbeam avenue and more central oak avenue have many trees with TCs above $220 \mathrm{~cm}$. Tree stands of Doły and Mania cemeteries are less imposing, although there are trees exceeding TCs of $200 \mathrm{~cm}$. It is worth mentioning that in recognition of the weight of Old Cemetery all its three parts were listed to national register of historic monuments in 1980 (Narodowy Instytut Dziedzictwa... 2017). What is more, 35 years later, in 2015, the cemetery has been recognized as a Polish historical monument (Niektóre tódzkie zabytki... 2017).

Measured growth of the Old Cemetery tree stand confirms its value. It reached distinguishing dimensions and continues to grow.

The main the maple-beech-hornbeam avenue in the Old Cemetery should be protected as nature monument. The same applies to the oak avenue farther to the west and group of trees in south-western part of the cemetery. 
The group of cemeteries along the Lodka River - both decommissioned and existing follow similar pattern of distribution. The only factor deciding on moving away the places of foundation of the cemeteries to east or west from old city centre is growth of the city.

\section{References}

Budnik A., Liczbińska G., Gumna I., 2004, Demographic trends and biological status of historic populations from central Poland: the Ostrow Lednicki microregion, "American Journal of Physical Anthropology", 125: 369-381.

Cmentarium sowa website, 2007, http://cmentarium.sowa.website.pl/Cmentarze/Lodz01. html [Accessed 5 Apr. 2017].

Cmentarze gdańskie, 2017, http://www.cmentarze-gdanskie.pl/cmentarze/chapter_77056. asp [Accessed 5 Apr. 2017].

Cmentarze-lodz. Cmentarze Archidiecezji Łódzkiej, http://www.cmentarze-lodz.pl/sw-antoniego-(mania)-lodz,historia.html [Accessed 15 Apr. 2017].

Dominikowski J., 2004, Nekropolia Lodzi Wielkoprzemystowej. Cmentarz Stary przy ulicy Ogrodowej. Dzieje i Sztuka 1854-1945, Wydawnictwo Konserwatorów, Dział Sztuki Łódź: 61-65.

Dziennik Urzędowy Województwa Łódzkiego, 1990, nr 3 (31 stycznia), poz. 24, Urząd Wojewódzki, Łódź.

Faliński J.B., 1990-1991, Kartografia geobotaniczna, cz. I, PPWK, Warszawa-Wrocław: $1-284$.

Geoserwis, 2020, http://geoserwis.gdos.gov.pl/mapy/?showExternalObject=BBC20AEC A7923E224E3E034CEB9B847A [Accessed 5 July 2020].

Głąb Z., 2007, Stary Rynek w Lodzi w latach 1414-1820. Zabudowa i funkcje, http://www. historycznie.uni.lodz.pl/rynek_hist.htm [Accessed 10 Apr. 2017].

Grzegorczyk A., 2011, Ilustrowana encyklopedia historii Łodzi, 2: 1-32.

Janczak J., 1982, Ludność Łodzi przemystowej 1820-1914, tab. 1, Łódź.

Koter M., 1974, Zagospodarowanie przestrzenne obszaru obecnej Łodzi u schytku okresu przedprzemystowego, „Materiały i Studia”, 4, Rada Naukowa przy Prezydencie m. Łodzi, Łódź.

Krawczyk Ł., 2007, http://www.historycznie.uni.lodz.pl/mapy_lodz.htm [Accessed 15 Apr. 2017].

Krawczyk Ł., 2007, http://www.historycznie.uni.lodz.pl/prawa.htm [Accessed 15 Apr. 2017].

Krawczyk Ł., 2007, http://www.historycznie.uni.lodz.pl/wies1.htm [Accessed 15 Apr. 2017].

Liszewski S., 1999, Ewolucja funkcji regionotwórczych w Lodzi, "Acta Universitatis Lodziensis. Folia Geographica Socio-Oeconomica", 1, Wydawnictwo Uniwersytetu Łódzkiego.

Ludność $w$ wieku 60 lat $i$ więcej, 2016, [note] https://www.google.pl/url?sa=t\&rct=j\&q= \&esrc $=$ s\&source $=$ web\&cd $=1 \& v e d=0$ ahUKEwiMOD91ZfTAhXC2xoKHdwEAswQF ggcMAA\&url=http\%3A\%2F\%2Fstat.gov.pl\%2Fdownload\%2Fgfx\%2Fportalinforma 
cyjny $\% 2 \mathrm{Fpl} \% 2 \mathrm{Fdefaultaktualnosci} \% 2 \mathrm{~F} 5468 \% 2 \mathrm{~F} 24 \% 2 \mathrm{~F} 1 \% 2 \mathrm{~F} 1 \% 2 \mathrm{Fludnosc}$ w_wieku_60._struktura_demograficzna_i_zdrowie.pdf\&usg=AFQjCNGYC5M36jMOsQo BBHi9MyyQUctUqQ [Accessed 5 Apr. 2017].

Narodowy Instytut Dziedzictwa: Rejestr zabytków nieruchomych - województwo łódzkie, https://pl.wikipedia.org/wiki/Stary_Cmentarz_w_\%C5\%81odzi\#Przypisy [Accessed 30 Dec. 2017]

Niektóre tódzkie zabytki prezydent Bronisław Komorowski wpisat na listę pomników historii, https://pl.wikinews.org/wikiNiekt $\%$ C3\%B3re_\%C5\%82\%C3\%B3dzkie_zabytki_prezydent_Bronis\%C5\%82awKomorowski_wpisa $\%$ C5\%82_na_list $\%$ C4\%99_pomnik\%C3\%B3w_historii [Accessed 30 Dec. 2017].

Papińska E., 2001, Wplyw antropopresji na przemiany środowiska geograficznego województwa łódzkiego, „Acta Geographica Lodziensia”, 81, Łódzkie Towarzystwo Naukowe.

Pawlak M., 2014, Historia-zapisana-w-kamieniu-cmentarz-stary [blog], http://magdalena-pawlak.blog.pl/2014/10/31/ [Accessed 5 Apr. 2017].

Tabela wiekowa drzew, opracowanie prof. dr Longin Majdecki 1980/1986 (1980), https://www.google.pl/search?q=Majdecki+1980+tabela+wielko\%C5\%9Bci+drzew\& ie $=$ utf-8\&oe=utf-8\&client=firefox-b\&gfe_rd=cr\&ei=yc71WI2UOsbi8AexmoGQDQ\# [Accessed 5 Apr. 2017].

Trwanie życia w 2015 [Life expectancy tables 2015], Informacje i Opracowania Statystyczne, Główny Urząd Statystyczny, 2016, http://stat.gov.pl/obszary-tematyczne/ludnosc/trwanie-zycia/trwanie-zycia-w-2015-r-,2,10.html [Accessed 5 Apr. 2017].

Urząd Miasta Łodzi, Protestantyzm, https:/uml.lodz.pl/dla-mieszkancow/zabytki/promocja-dziedzictwa-kulturowego/sciezka-4-wyznan/protestantyzm/ [Accessed 5 July 2020].

Wiercińska A., 2012, Cmentarze tódzkie na tle rozwoju ludnościowego i przestrzennego miasta, „Studia z Geografii Politycznej i Historycznej”, 1: 207-220.

Winnik A., 2005, Dendroflora Cmentarza Starego przy ul. Ogrodowej w Łodzi (część ewangelicko-augsburska i prawosławna), praca magisterska, Zakład Ochrony Przyrody, Uniwersytet Łódzki, Łódź.

Zwik.lodz.rzeki-lodzi, 2017, http://www.zwik.lodz.pl/rzeki-lodzi/rzeka-balutka/

\section{DRZEWOSTAN STAREGO CMENTARZA W LODZI I MIEJSCE STAREGO CMENTARZA WŚRÓD LÓDZKICH CMENTARZY NAD RZEKĄ LÓDKĄ}

Zarys treści: Artykuł dotyczy drzewostanu Starego Cmentarza przy ul. Ogrodowej w Łodzi. W głównej alei zmierzono obwody drzew w pierśnicy. Zmierzono również pierśnice innych drzew na tym cmentarzu, a także na dwóch innych. Dokonano oceny wartości drzewostanu Starego Cmentarza.

Słowa kluczowe: drzewostan, obwód pnia, BHT, powierzchnia cmentarza, data założenia cmentarza, Stary Cmentarz w Lodzi, walory przyrodnicze.

Dr Tomasz Otocki

Independent researcher e-mail: tomaszotocki@vp.pl 